\title{
Factors moderating Listeria monocytogenes growth in raw milk and in soft cheese made from raw milk
}

\author{
Marielle GAY, Albert AMGAR* \\ Association ASEPT, BP 2047, 53020 Laval Cedex 9, France
}

Received 1 December 2004 - Accepted 8 February 2005

Published online 26 April 2005

\begin{abstract}
Listeria monocytogenes is a foodborne pathogenic bacterium sometimes found in raw milk. Raw milk contains natural bacterial inhibitors such as the lactoperoxidase system (LPS) and specific microflora. Six strains of L. monocytogenes isolated from raw milk in 1995 and 1996 in Normandy (France) were tested. The aim of the first part of this work was to evaluate the inhibitory effect of LPS on L. monocytogenes in milk. Kept at $15^{\circ} \mathrm{C}$ for $65 \mathrm{~h}$, in static conditions, populations of $L$. monocytogenes in pasteurized milk increased by 2 to 3.8 log depending on the strain. In raw milk, in the same conditions, populations increased by 0.8 to $2.3 \mathrm{log}$. Adding thiocyanate and hydrogen peroxide to raw milk (supplemented raw milk, SRM) enhanced its inhibitory effect. In SRM, three strains were unable to grow and the populations of the other strains increased by 0.7 to $1.3 \mathrm{log}$. The inhibitory effect of the LPS in milk was clearly demonstrated. The inhibitory effect of raw milk on L. monocytogenes was due to LPS, probably combined with the microbiological composition of raw milk. The aim of the second part of this work was to evaluate the inhibitory effect of using raw milk for making Camembert cheese (RMC). The results show that the growth of L. monocytogenes was about twice as slow in RMC as in Camembert made from pasteurized milk (PMC). The average lag phase (Lag) was $15 \mathrm{~d}$ in PMC and $34 \mathrm{~d}$ in RMC. Statistical analysis showed that the inhibitory effect of RMC on the growth of L. monocytogenes was mainly related to the microbiological composition of the raw milk, in terms of thermophilic Lactobacillus and yeast. Although our results did not clearly demonstrate an inhibitory effect of chemical composition of raw milk, inhibition of $L$. monocytogenes in RMC is probably due to the interrelationship between microbiological and chemical factors.
\end{abstract}

\section{Listeria monocytogenes / inhibition / raw milk / lactoperoxidase system}

Résumé - Facteurs ralentissant la croissance de Listeria monocytogenes dans le lait cru et dans les fromages à pâte molle au lait cru. Six souches de L. monocytogenes isolées de lait cru en 1995 et 1996 (Normandie) sont utilisées. L'effet du système lactopéroxydase (LPS), inhibiteur de croissance microbienne naturellement présent dans le lait cru, sur L. monocytogenes, est évalué. Dans le lait pasteurisé incubé $65 \mathrm{~h}$ à $15^{\circ} \mathrm{C}$, la population de L. monocytogenes, augmente de 2 à $3,8 \log$ selon les souches. Dans le lait cru, la population augmente de 0,8 à $2,3 \log$. L'ajout de thiocyanate et de péroxyde d'hydrogène au lait cru (SRM) accroît son effet inhibiteur. Dans le SRM, trois souches ne se développent pas ; pour les autres, la population augmente de 0,7 à $1,3 \log$. L'effet inhibiteur du lait cru sur L. monocytogenes est lié à la présence de LPS, et probablement à la composition microbiologique du lait cru. La croissance de L. monocytogenes dans le Camembert est également étudiée. Les résultats montrent que $L$. monocytogenes se développe environ deux fois plus lentement dans le Camembert au lait cru (RMC) que dans celui au lait pasteurisé (PMC). Les durées moyennes des

\footnotetext{
* Corresponding author: asept@asept.fr
} 
phases de latence sont de 15 et 34 j, respectivement dans le PMC et le RMC. L'effet inhibiteur du RMC est principalement lié à la composition microbiologique du lait cru, en particulier la présence de lactobacilles thermophiles et de levures.

\section{Listeria monocytogenes / inhibition / lait cru / lactopéroxydase}

\section{INTRODUCTION}

Listeria monocytogenes is a foodborne pathogenic bacterium that can cause listeriosis. It affects the young, the elderly, pregnant women and persons with weakened immune systems. L. monocytogenes has been implicated in meningitis, abortion, septicemia and infection with a lethality as high as $30 \%[14,36]$. It is a ubiquitous bacterium, able to grow in ready-to-eat foods including dairy products $[13,20,23,25,31$, 39]. L. monocytogenes is psychrotrophic and can grow in acid conditions [19]. The behavior of L. monocytogenes is related to its initial concentration and the pre-incubation conditions [17].

Raw milk can be contaminated with L. monocytogenes. Examples of the incidence of L. monocytogenes in raw milk cited in the literature are $2.3 \%$ in Canada, $3.2 \%$ in USA, $3.6 \%$ in Europe [38] and 2.4\% in France [28]. Raw milk can be contaminated as a result of environmental hygiene conditions during milking, or can be contaminated directly by the cattle, which may sometimes shed $L$. monocytogenes in their milk as a result of listerial mastitis, encephalitis or abortion. In general, contamination due to environmental hygiene during milking is weak (below $3 \mathrm{cfu} \cdot \mathrm{mL}^{-1}$ with most probable concentration $0.1 \mathrm{cfu} \cdot \mathrm{mL}^{-1}$, [28]). Direct contamination from dairy cattle can be higher than $10^{3} \mathrm{cfu} \cdot \mathrm{mL}^{-1}[38,40]$.

Raw milk contains bacterial inhibitors such as the lactoperoxidase system (LPS) [1]. The LPS is composed of an enzyme, lactoperoxidase (LP); an oxidative agent, hydrogen peroxide $\left(\mathrm{H}_{2} \mathrm{O}_{2}\right)$; and a substrate, the thiocyanate $\left(\mathrm{SCN}^{-}\right)$. The oxidation product $\left(\mathrm{OSCN}^{-}\right)$can react with the amine and thiol groups of the enzymes essential for bacterial metabolism. LPS has a bacteriostatic effect on Gram-positive bacteria including L. monocytogenes, and is inactivated in pasteurized milk [32].
Soft cheese can become contaminated with L. monocytogenes owing to contaminated raw materials or lack of hygiene during manufacture, storage and distribution. Soft cheeses have been implicated in foodborne outbreaks [43]. The inhibitory effect of raw milk on several pathogens including L. monocytogenes [33] can indicate that L. monocytogenes grows more slowly in raw milk cheese than in cheese made from pasteurized milk. Factors that can limit growth are the LPS, lactic acid bacteria (which are sometimes bacteriocin producers), competition for nutrients, steric limitations, etc. $[6,14,35]$. Technological parameters such as low $\mathrm{pH}$ or $\mathrm{a}_{\mathrm{w}}$ can also have an effect on the behavior of L. monocytogenes in cheese.

The study had two aims. The first was to evaluate the inhibitory effect of the LPS in milk. The second was to compare the growth of $L$. monocytogenes in artificially contaminated soft cheeses made from pasteurized and from raw milk, and determine factors pertaining to raw milk components, raw milk microbial flora and cheese-making technology that may have an inhibitory effect on L. monocytogenes.

\section{MATERIALS AND METHODS}

\subsection{L. monocytogenes strains}

\subsubsection{Strains}

Six strains of L. monocytogenes isolated from raw milk in 1995 and 1996 in Normandy (France) were used throughout the study. All strains were from a private collection (strains $\mathrm{N}^{\circ} 315-734 ; 314-501 ; 360$ 248 ; 348-38; 346-209; and 307-163).With the aim of simplifying reading of this paper, the strains were recalled 1,2, 3, 4, 5 and 6 . 


\subsubsection{Typing of L. monocytogenes strains}

The six strains were serotyped and phage-typed by the Centre National de Référence des Listeria (Institut Pasteur, Paris, France). For pulsed field gel electrophoresis (PFGE) analysis, Brain Heart Infusion Broth (BHI, Difco, Grenoble, France) was inoculated with a single colony. Cells were harvested from $8 \mathrm{~mL}$ of broth after overnight incubation at $37{ }^{\circ} \mathrm{C}$. DNA isolation was performed in Low Melting Point agarose plugs $\left(125 \mathrm{mmol} \cdot \mathrm{L}^{-1}\right)$, as described by Brosch et al. [10], modified by the use of a lysis solution containing $0.5 \mathrm{~mol} \cdot \mathrm{L}^{-1}$ EDTA-0.5\% Sarcosyl (Sigma, Saint-Quentin-Fallavier, France), $2 \mathrm{mg} \cdot \mathrm{mL}^{-1}$ desoxycholic acid (Sigma), and $2.5 \mathrm{mg} \cdot \mathrm{mL}^{-1}$ lysozyme (Appligene, Illkirch-Graffenstaden, France). The restriction endonuclease used for digestion was Smal (Boehringer, Reims, France and Amersham, Orsay, France). The samples were eletrophoresed at $200 \mathrm{~V}$ and $15^{\circ} \mathrm{C}$ in the CHEF DRIII system (Biorad, Ivry-sur-Seine, France). The pulsed times ranged from 1 to $12 \mathrm{~s}$ for $17 \mathrm{~h}$. The gels were stained with ethidium bromide and photographed under UV transillumination. The PFGE patterns were analyzed with the Molecular Analyst software (Biorad). Similarities between macrorestriction patterns were expressed by Jaccard coefficient correlation by the UPGMA method (unweighted pair group using arithmetic averages) (minimum Profiling 5\%, minimum Area $0.5 \%$, position tolerance $1.2 \%$ ).

\subsection{Chemical analyses of milk}

Chemical analyses were performed on the raw milk samples (before pasteurization or addition of thiocyanate and hydrogen peroxide) used throughout this study. Lactoperoxidase (LP) activity was determined according to the method described by Kumar and Bhatia [24]. The milk samples were analyzed in triplicate. The thiocyanate $\left(\mathrm{SCN}^{-}\right)$concentration in the milk was determined using the method described by Hoogendoorn et al. [22]. Milk samples were analyzed in duplicate.

\subsection{Microbiological analyses of milk}

Twenty-five milliliters of each raw milk sample were analyzed for the presence of $L$. monocytogenes, according to the ISO 11290-1 standard [2]. To evaluate the microbiological quality of milk, enumerations of thermophilic Lactobacillus, mesophilic Lactobacillus, Enterobacteriaceae, Enterococcus, Pseudomonas, Micrococcus, Coryneform bacteria and yeast were performed. Table I summarizes the microflora enumeration techniques employed.

\subsection{Behavior of L. monocytogenes in milk}

\subsubsection{Milk samples}

Eight milk samples were used to study the behavior of L. monocytogenes in milk. Samples A, B and C were used raw. Samples D, E and F were pasteurized at $75^{\circ} \mathrm{C}$ for $15 \mathrm{~s}$ in a small plate heat-exchanger type V8 (Vicarb, Fontanil-Cornillon, France). Chemical and microbiological analyses were performed on these three samples before pasteurization. The last two samples ( $\mathrm{G}$ and $\mathrm{H}$ ) and sample $\mathrm{C}$ were used raw with added $\mathrm{H}_{2} \mathrm{O}_{2}$ (Labogros, Buchs, France) and NaSCN (Sigma). The concentrations added were $0.25 \mathrm{mmol} \cdot \mathrm{L}^{-1}$, both for thiocyanate and for hydrogen peroxide. Chemical and microbiological analyses were performed before adding the thiocyanate and hydrogen peroxide to the raw milk. Different milk samples were used for the different situations (pasteurized, raw, SRM and different strains) because of experimental constraints.

\subsubsection{Inoculum preparation}

Ten microliters of frozen culture was prepared on slants of Tryptone Soya Agar (TSA, Oxoid, Dardilly, France) and incubated at $30{ }^{\circ} \mathrm{C}$ for $24 \mathrm{~h}$. Bacteria were then inoculated into $10 \mathrm{~mL}$ of Tryptone Soya Broth (TSB, Oxoid) and incubated at $30{ }^{\circ} \mathrm{C}$ for $24 \mathrm{~h}$. Then $0.1 \mathrm{~mL}$ of this culture was transferred into $10 \mathrm{~mL}$ of sterile TSB and incubated at $30{ }^{\circ} \mathrm{C}$ for $24 \mathrm{~h}$. This incubation regime resulted in a stationary phase culture with approximately $10^{9} \mathrm{cfu} \cdot \mathrm{mL}^{-1}$. Five hundred 
Table I. Microbiological techniques used to analyze raw milk samples.

\begin{tabular}{|c|c|c|c|}
\hline \multirow[t]{2}{*}{ Microbiological flora } & \multirow[t]{2}{*}{ Technique and Medium } & \multicolumn{2}{|c|}{ Incubation } \\
\hline & & $\begin{array}{c}\text { Temperature } \\
\left({ }^{\circ} \mathrm{C}\right)\end{array}$ & Time \\
\hline \multirow[t]{2}{*}{ Thermophilic Lactobacillus } & Pour plate - M17 agar ${ }^{2}$ & 42 & $72 \mathrm{~h}$ \\
\hline & Spread plate - MRS agar ${ }^{1}$ & 42 & $72 \mathrm{~h}$ \\
\hline \multirow[t]{2}{*}{ Mesophilic Lactobacillus } & Pour plate - M17 agar 2 & 30 & $72 \mathrm{~h}$ \\
\hline & Spread plate - MRS agar ${ }^{1}$ & 30 & $72 \mathrm{~h}$ \\
\hline Enterobacteriaceae & $\begin{array}{l}\text { Pour plate - Violet Red Bile Glucose Agar } \\
\text { (VRBGA) }^{2}\end{array}$ & 30 & $24 \mathrm{~h}$ \\
\hline Enterococcus & $\begin{array}{l}\text { Spread plate - Citrate Azide Tween Carbonate } \\
\text { Agar (CATC agar) }{ }^{3}\end{array}$ & 37 & $24 \mathrm{~h}$ \\
\hline Pseudomonas & $\begin{array}{l}\text { Spread plate - Pseudomonas aeromonas } \\
\text { Selective Agar Base acc. to Kielwein } \\
\text { (GSP agar) }{ }^{3}\end{array}$ & 25 & $72 \mathrm{~h}$ \\
\hline Micrococcus & $\begin{array}{l}\text { Spread plate - Tryptone Soya Agar } \\
\text { (TSA) }+3 \% \mathrm{NaCl} \text { agar }{ }^{2}\end{array}$ & 30 & $72 \mathrm{~h}$ \\
\hline Coryneform bacteria & Spread plate $-\mathrm{TSA}+3 \% \mathrm{NaCl}$ agar $^{2}$ & 30 & $72 \mathrm{~h}$ \\
\hline Yeast & Pour plate - Chloramphenicol Glucose Agar ${ }^{2}$ & 25 & $5 \mathrm{~d}$ \\
\hline
\end{tabular}

${ }^{1}$ Difco; ${ }^{2}$ Biokar Diagnostics; ${ }^{3}$ Merck.

milliliters of milk (in a 1-liter flask) were inoculated with $1 \mathrm{~mL}$ of diluted inoculum to reach the desired initial concentration (approximately $10^{3} \mathrm{cfu} \cdot \mathrm{mL}^{-1}$ ).

\subsubsection{Incubation temperature of L. monocytogenes in milk}

The temperatures tested were $3{ }^{\circ} \mathrm{C}, 9^{\circ} \mathrm{C}$ and $15^{\circ} \mathrm{C}$. Each experiment (one milk type, one temperature and one strain) was carried out in duplicate. The experimental design is presented in Table II.

\subsubsection{Numeration of L. monocytogenes in milk}

The six L. monocytogenes strains were inoculated separately in the eight milk samples. Plates of Palcam (Oxoid) were spread with $0.1 \mathrm{~mL}$ inoculum and incubated for $24 \mathrm{~h}$ to $48 \mathrm{~h}$ at $30^{\circ} \mathrm{C}$. Each milk sample was enumerated twice a day over a period of $65 \mathrm{~h}$ (values given were the mean of two independent experiments).

\subsection{Main steps in the cheese-making}

Eighteen milk samples were taken on different occasions (from April through August) from the same farm tank on the day of collection (after four milkings).

Eight raw milk samples were pasteurized $\left(75^{\circ} \mathrm{C}\right.$ for $\left.15 \mathrm{~s}\right)$ in a small plate heatexchanger (Vicarb, type V8) to make pasteurized milk cheese (PMC) and ten were not, to make raw milk cheese (RMC). Milk samples used to make PMC and RMC were always different, because of cheese-making restraints. The milk was skimmed at 50$55^{\circ} \mathrm{C}$. Fat concentration was standardized to $28 \mathrm{~g} \cdot \mathrm{L}^{-1}$, and the milk was put in four different 50 -liter vats. One of these was used as control and was not inoculated with L. monocytogenes. The other three were inoculated with three different $L$. monocytogenes strains $\left(5 \times 10^{-1} \mathrm{cfu} \cdot \mathrm{mL}^{-1}\right.$, one strain per vat). The milk was inoculated with mixed mesophilic lactic starter culture (MM100 and MM101, $0.6 \mathrm{U} \cdot 100 \mathrm{~mL}^{-1}$, Rhodia Food, Saint-Fons, France) and Micrococcus (MVA, 0.5 dose per $1000 \mathrm{~L}$, 
Table II. Experimental design used to study behavior of $L$. monocytogenes in milk.

\begin{tabular}{ccccc}
\hline Milk sample & $\begin{array}{c}\text { Collecting date } \\
\text { (day/month) }\end{array}$ & Milk type & Inoculated strains & $\begin{array}{c}\text { Incubation temperatures } \\
\left({ }^{\circ} \mathrm{C}\right)\end{array}$ \\
\hline A & $07 / 07$ & Raw & $2,3,4,5,6$ & 3,9 and 15 \\
B & $15 / 07$ & Raw & 1,6 & 3,9 and 15 \\
C & $24 / 08$ & Raw & $1,2,3,4,5$ & 3,9 and 15 \\
& & SRM ${ }^{\text {a }}$ & $1,2,5,6$ & 3,9 and 15 \\
D & $23 / 06$ & Pasteurized & $1,2,3,4$ & 3,9 and 15 \\
E & $21 / 07$ & Pasteurized & $3,4,5,6$ & 3,9 and 15 \\
F & $27 / 07$ & Pasteurized & $1,2,5,6$ & 3,9 and 15 \\
G & $04 / 08$ & SRM & $1,2,3,4$ & 3,9 and 15 \\
H & $10 / 08$ & SRM & $3,4,5,6$ & 3,9 and 15 \\
\hline
\end{tabular}

${ }^{a}$ Supplemented raw milk: adding thiocyanate and hydrogen peroxide to raw milk.

Rhodia). The milk was cold-ripened at $12{ }^{\circ} \mathrm{C}$ for $15 \mathrm{~h}$. It was then inoculated with Penicillium camembertii (Neige, 0.5 dose per 1000 L, Rhodia), Geotrichum candidum (Géo17, 0.5 dose per 1000 L, Rhodia) and mesophilic acid starter culture (MA011 and MA014, $0.35 \mathrm{U}$ per $100 \mathrm{~L}$, Rhodia). The milk was ripened for $20 \mathrm{~min}$ at $38{ }^{\circ} \mathrm{C}$ (warm ripening). The clotting agent (rennet extract Carlin, Rhodia) was added to the milk at $35{ }^{\circ} \mathrm{C}(\mathrm{pH}=6.35)$. Coagulation occurred in $40 \mathrm{~min}$. The curd was cut into 2-cm cubes, healed for $25 \mathrm{~min}$, drained and transferred to moulds. The moulds were turned after 1, 2 and $3 \mathrm{~h}$. The cheeses were removed from the moulds and stored at $12{ }^{\circ} \mathrm{C}$ for $6 \mathrm{~h}$ before brining in a saturated sodium chloride solution (content of $\mathrm{NaCl}$ in cheese was $1.6 \% \mathrm{w} / \mathrm{w}$ ). The cheeses were inoculated on their surface by spraying Penicillium camembertii (Neige, 1 dose per $500 \mathrm{~mL}$ ) and Geotrichum candidum (Géo17, 0.5 dose per $500 \mathrm{~mL}$ ). They were then drained and placed in a drying room for $24 \mathrm{~h}$ at $12{ }^{\circ} \mathrm{C}$. They were then ripened at $11^{\circ} \mathrm{C}$ with $85-95 \%$ relative humidity for $14 \mathrm{~d}$, then packaged and stored at $4{ }^{\circ} \mathrm{C}$ for $40 \mathrm{~d}$ (i.e. until $55 \mathrm{~d}$ after manufacture).

The cheeses made from the control vat of milk were used to measure technological parameters during manufacture.

\subsection{Behavior of L. monocytogenes in cheese}

Inoculum preparation was the same as was used for inoculating $L$. monocytogenes in the milk samples. Strains were individually inoculated into milk after standardizing fat content. Initial bacterial concentration was approximately $5 \times 10^{-1} \mathrm{cfu} \cdot \mathrm{mL}^{-1}$ of milk. As three different $L$. monocytogenes strains were studied from one cheese production, ten cheese productions from raw milk enabled us to study five-fold the six L. monocytogenes strains. Eight cheese productions from pasteurized milk enabled us to study four-fold the six L. monocytogenes strains.

Enumeration of L. monocytogenes was performed during cheese manufacture, ripening and storage. L. monocytogenes was enumerated (i) at the beginning of the cold ripening of the milk, (ii) at the end of the warm ripening of the milk, (iii) when the curd was ladled into moulds, (iv) during destacking, (v) at the end of draining, (vi) after $7 \mathrm{~d}$ of ripening at $11{ }^{\circ} \mathrm{C}$, (vii) at packaging, and six times during storage at $4{ }^{\circ} \mathrm{C}$ (after 5, 12, 19, 26, 33 and $40 \mathrm{~d}$ ).

Enumeration of L. monocytogenes in the milk at the beginning of cold ripening (i) and at the end of the warm ripening (ii) was performed by the following method. Ten milliliters of milk were spread on five Palcam 

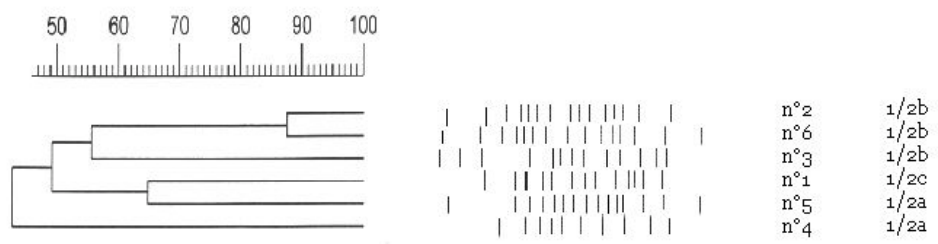

1967:4477:575:1806 $1967: 4477: 10: 43: 1806$ NT 4477:12029 NT NT

NT : not typable

Figure 1. Pulsotype, serotype and lysotype of the six L. monocytogenes strains used throughout the study.

agar (Oxoid) Petri dishes (diameter $140 \mathrm{~mm}$ ) and incubated at $37^{\circ} \mathrm{C}$ for $48 \mathrm{~h}$. The detection threshold was $10^{-1} \mathrm{cfu} \cdot \mathrm{mL}^{-1}$. Samples were enumerated in duplicate.

For enumeration of L. monocytogenes in the curd (during manufacture and ripening and at packaging, iii, iv, v, vi and vii), samples were enumerated in duplicate. Ten grams of cheese were diluted in $40 \mathrm{~mL}$ of Tryptone salt broth. One milliliter of this dilution was spread on five Palcam agar (Oxoid) Petri dishes (diameter $90 \mathrm{~mm}$ ) and incubated at $37{ }^{\circ} \mathrm{C}$ for $48 \mathrm{~h}$. The detection threshold was $5 \mathrm{cfu} \cdot \mathrm{mL}^{-1}$.

Enumeration of L. monocytogenes during storage was performed on $20 \mathrm{~g}$ of cheese diluted in $80 \mathrm{~mL}$ of Tryptone salt broth. One milliliter of this dilution (or $1 \mathrm{~mL}$ of the appropriate decimal dilution) was spread on 5 Palcam agar (Oxoid) Petri dishes (diameter $90 \mathrm{~mm}$ ) and incubated at $37{ }^{\circ} \mathrm{C}$ for $48 \mathrm{~h}$. The detection threshold was $5 \mathrm{CFU} \cdot \mathrm{mL}^{-1}$. The samples were enumerated in duplicate.

For each cheese production, 30 colonies of each L. monocytogenes strain were isolated at the end of the experimental period (56 d). PFGE profiles were determined to verify that the enumerated strains were those that had been inoculated into the milk.

\subsection{Statistical analysis}

The effect of raw milk composition (microbiological and chemical concentrations) on the behavior of $L$. monocytogenes in Camembert cheese was evaluated by principal components analysis with Statgraphics (Uniware, Bromley, UK). Chemical values were used directly and microbiological parameters were log transformed before analysis. Two distinguishing growth curve parameters were determined to characterize the growth of $L$. monocytogenes in cheese. These two parameters were the lag phase (Lag) and time to a $10^{3}$ increase in population in the curd $\left(\mathrm{T} 10^{3}\right)$. When no growth was observed during the $56 \mathrm{~d}$ of the experiment, Lag and $\mathrm{T} 10^{3}$ were arbitrarily set at 80 and $100 \mathrm{~d}$, respectively. When growth was observed but $\mathrm{T} 10^{3}$ was longer than the 56-day experiment period, $\mathrm{T} 10^{3}$ was arbitrarily set at $80 \mathrm{~d}$.

\section{RESULTS}

\subsection{Characterization of L. monocytogenes strains}

The six strains (all taken from raw milk) were characterized by their pulsotype, serotype and lysotype (Fig. 1). The results from serotype indicated that the strains belong to serotypes $1 / 2 \mathrm{a}$ (strains 4 and 5), 1/2b (strains 2,3 and 6 ) and $1 / 2 \mathrm{c}$ (strain 1). The results from lysotype indicated that strains 2,3 and 6 were different. The results from PFGE profiles and from similarity between strains indicated that strains 4 and 5 were different (less than 50\% similarity). The results indicated that all six strains were different. 
Table III. Lactoperoxidase and thiocyanate concentrations in milk samples used to evaluate effect of LPS on L. monocytogenes in milk. These analyses were performed on raw milk samples (before pasteurization or before addition of thiocyanate and hydrogen peroxide).

\begin{tabular}{lccc}
\hline Milk sample & $\begin{array}{c}\text { Collecting date } \\
(\text { day/month })\end{array}$ & $\begin{array}{c}\text { Lactoperoxidase } \\
\text { concentration }\left(\mu \mathrm{g} \cdot \mathrm{mL}^{-1}\right)\end{array}$ & $\begin{array}{c}\text { Thiocyanate } \\
\text { concentration }\left(\mu \mathrm{g} \cdot \mathrm{mL}^{-1}\right)\end{array}$ \\
\hline A & $07 / 07$ & 38.9 & 5.94 \\
B & $15 / 07$ & 28.5 & 4.32 \\
C & $24 / 08$ & 36.1 & 5.03 \\
D & $23 . / 06$ & 21.7 & 4.94 \\
E & $21 / 07$ & 25.8 & 4.54 \\
F & $27 / 07$ & 33.0 & 4.43 \\
G & $04 / 08$ & 48.6 & 6.53 \\
H & $10 / 08$ & 40 & 5.17 \\
Average & & 34.1 & 5.11 \\
\hline
\end{tabular}

\subsection{Chemical analysis of the eight milk samples used to evaluate effect of LPS in milk}

The average value for lactoperoxidase concentration was $34.1 \mu \mathrm{g} \cdot \mathrm{mL}^{-1}$ (Tab. III). Lactoperoxidase concentrations were found to differ widely from sample to sample. The minimum and maximum concentrations were $21.7 \mu \mathrm{g} \cdot \mathrm{mL}^{-1}$ and $48.6 \mu \mathrm{g} \cdot \mathrm{mL}^{-1}$, respectively. The minimum concentration was observed in a sample taken in June. The average value for thiocyanate concentration was $5.11 \mu \mathrm{g} \cdot \mathrm{mL}^{-1}\left(\right.$ range $\left.4.32-6.53 \mu \mathrm{g} \cdot \mathrm{mL}^{-1}\right)$.

\subsection{Microbiological analysis of the eight milk samples used to evaluate effect of LPS in milk}

No L. monocytogenes cells were found in the $25-\mathrm{mL}$ milk samples. Some differences were observed in the microflora composition (Tab. IV). The main microflora encountered in raw milk samples B, C and $\mathrm{H}$ was Pseudomonas $(74.8 \%, 47.3 \%$ and $86 \%$, respectively). In sample C, there were high proportions of coryneform bacteria and yeasts; $10.9 \%$ and $5.5 \%$, respectively, against less than $0.15 \%$ and less than $0.4 \%$ in the other two samples (B and $\mathrm{H}$ ). For milk samples A, D, E, F and G, percentages of Pseudomonas were $30.5 \%, 30.0 \%, 18.8 \%$,
$13.8 \%$ and $15.2 \%$, respectively. In samples D, F and G, mesophilic Lactobacillus was the main microflora (more than $60 \%$ ). For sample A, Enterococcus was the main microflora $(55.6 \%)$. For sample E, the main microflora was represented by mesophilic Lactobacillus (28.8\%), Micrococcus (28.8\%) and thermophilic Lactobacillus (10.4\%).

\subsection{Behavior of L. monocytogenes in milk}

In pasteurized milk (samples $\mathrm{D}, \mathrm{E}$ and $\mathrm{F}$, Tabs. III and IV) strains 1, 2, 5 and 6 were unable to grow at $3{ }^{\circ} \mathrm{C}$ for $65 \mathrm{~h}$ (Fig. 2A). Their populations increased by less than $0.5 \log$. The populations of strains 3 and 4 increased by 0.8 and $1.0 \log$ during the $65 \mathrm{~h}$ of incubation. At $9{ }^{\circ} \mathrm{C}$ and $15{ }^{\circ} \mathrm{C}$, all tested strains were able to grow in pasteurized milk. At $9{ }^{\circ} \mathrm{C}$, populations increased by between $0.5 \log$ (strain 3$)$ and $1.8 \log ($ strain 4$)$. At $15{ }^{\circ} \mathrm{C}$, the average population increase was $3.1 \mathrm{log}$ during the incubation period. The range was between $2.7 \log$ (strain 2) and $3.8 \log$ (strain 6). Values given for each strain were the mean of two independent experiments.

In raw milk (samples $\mathrm{A}, \mathrm{B}$ and $\mathrm{C}$, Tabs. III and IV) all tested strains were unable to grow at $3{ }^{\circ} \mathrm{C}$ for $65 \mathrm{~h}$ (less than $0.5 \mathrm{log}$ increase, Fig. $2 \mathrm{~B}$ ). At $9^{\circ} \mathrm{C}$, only strain 1 was 
Table IV. Microbiological analysis of milk samples used to evaluate effect of LPS on $L$. monocytogenes in milk. These analyses were performed on raw milk samples (before pasteurization or before addition of thiocyanate and hydrogen peroxide).

\begin{tabular}{|c|c|c|c|c|c|c|c|c|}
\hline \multirow[t]{2}{*}{$\begin{array}{l}\text { Microbiological } \\
\text { flora }\end{array}$} & \multicolumn{8}{|c|}{$\begin{array}{l}\text { Enumeration }\left(\mathrm{cfu} \cdot \mathrm{mL}^{-1}\right) \text { and percentage }{ }^{a} \text { of each microbiological flora in raw milk } \\
\text { samples }\end{array}$} \\
\hline & A & B & $\mathrm{C}$ & $\mathrm{D}$ & E & F & G & $\mathrm{H}$ \\
\hline Thermophilic & $6.5 \times 10^{2}$ & $1.7 \times 10^{2}$ & $8.3 \times 10^{2}$ & $1.3 \times 10^{2}$ & $8.3 \times 10^{2}$ & $1.1 \times 10^{2}$ & $2.0 \times 10^{3}$ & $6.1 \times 10^{2}$ \\
\hline Lactobacillus & $3.6 \%$ & $0.3 \%$ & $1.5 \%$ & $0.5 \%$ & $10.4 \%$ b & $0.3 \%$ & $3.8 \%$ & $0.1 \%$ \\
\hline Mesophilic & $8.3 \times 10^{2}$ & $1.5 \times 10^{4}$ & $1.6 \times 10^{4}$ & $1.7 \times 10^{4}$ & $2.3 \times 10^{3}$ & $3.4 \times 10^{4}$ & $5.2 \times 10^{4}$ & $1.5 \times 10^{5}$ \\
\hline Lactobacillus & $4.6 \%$ & $23.1 \%$ & $29.1 \%$ & $60.7 \%$ b & $28.8 \%$ b & $78.2 \%$ b & $78.8 \%$ b & $14.5 \%$ \\
\hline \multirow{2}{*}{ Enterobacteriaceae } & $4.2 \times 10^{1}$ & $1.0 \times 10^{2}$ & $2.4 \times 10^{2}$ & $1.5 \times 10^{2}$ & $2.0 \times 10^{2}$ & $4.2 \times 10^{2}$ & $3.0 \times 10^{2}$ & $1.4 \times 10^{3}$ \\
\hline & $0.2 \%$ & $0.2 \%$ & $0.4 \%$ & $0.5 \%$ & $2.5 \%$ & $1.0 \%$ & $0.5 \%$ & $0.1 \%$ \\
\hline \multirow{2}{*}{ Enterococcus } & $1.0 \times 10^{4}$ & $1.8 \times 10^{2}$ & $1.1 \times 10^{3}$ & $<10$ & $2.8 \times 10^{2}$ & $2.5 \times 10^{2}$ & $1.2 \times 10^{2}$ & $1.7 \times 10^{4}$ \\
\hline & $55.6 \%$ b & $0.3 \%$ & $2.0 \%$ & $<0.03 \%$ & $3.5 \%$ & $0.6 \%$ & $0.2 \%$ & $1.7 \%$ \\
\hline \multirow{2}{*}{ Pseudomonas } & $5.5 \times 10^{3}$ & $4.8 \times 10^{4}$ & $2.6 \times 10^{4}$ & $8.4 \times 10^{3}$ & $1.5 \times 10^{3}$ & $6.0 \times 10^{3}$ & $1.0 \times 10^{4}$ & $8.6 \times 10^{5}$ \\
\hline & $30.5 \%$ & $74.8 \%$ b & $47.3 \%$ b & $30.0 \%$ & $18.8 \%$ & $13.8 \%$ & $15.2 \%$ & $86.0 \%$ b \\
\hline \multirow{2}{*}{ Miсrococсиs } & $1.0 \times 10^{3}$ & $1.1 \times 10^{3}$ & $2.3 \times 10^{3}$ & $2.4 \times 10^{3}$ & $2.3 \times 10^{3}$ & $2.6 \times 10^{3}$ & $1.5 \times 10^{3}$ & $2.2 \times 10^{3}$ \\
\hline & $5.6 \%$ & $1.7 \%$ & $4.2 \%$ & $8.6 \%$ & $28.8 \%$ b & $6.0 \%$ & $2.3 \%$ & $0.2 \%$ \\
\hline \multirow{2}{*}{$\begin{array}{l}\text { Coryneform } \\
\text { bacteria }\end{array}$} & $<10^{2}$ & $1.0 \times 10^{2}$ & $6.0 \times 10^{3}$ & $<10^{2}$ & $4.0 \times 10^{2}$ & $<10^{2}$ & $1.0 \times 10^{2}$ & $3.0 \times 10^{2}$ \\
\hline & $<0.6 \%$ & $0.15 \%$ & $10.9 \%$ b & $<0.4 \%$ & $5.0 \%$ & $<0.2 \%$ & $0.15 \%$ & $0.03 \%$ \\
\hline \multirow{2}{*}{ Yeast } & $3.9 \times 10^{2}$ & $2.7 \times 10^{2}$ & $3.0 \times 10^{3}$ & $2.5 \times 10^{2}$ & $1.7 \times 10^{2}$ & $2.0 \times 10^{1}$ & $1.4 \times 10^{2}$ & $4.0 \times 10^{2}$ \\
\hline & $2.0 \%$ & $0.4 \%$ & $5.5 \%$ b & $0.9 \%$ & $2.1 \%$ & $0.05 \%$ & $0.2 \%$ & $0.04 \%$ \\
\hline
\end{tabular}

${ }^{a}$ Percentage of the amount of enumerated microflora; ${ }^{b}$ main encountered microbiological flora in each raw milk sample.

able to grow ( $0.7 \log$ increase). At $15{ }^{\circ} \mathrm{C}$, the increase was between $0.8 \log$ (strain 2) and $2.1 \log$ ( $\operatorname{strain} 6)$. The average value for the six strains was $1.4 \log$. Values given for each strain were the mean of two independent experiments.

The milk samples used as SRM (i.e. with added thiocyanate and hydrogen peroxide) were samples $\mathrm{C}, \mathrm{G}$ and $\mathrm{H}$ (Tabs. III and IV). Thiocyanate concentration in SRM was about $20 \mu \mathrm{g} \cdot \mathrm{mL}^{-1}\left(19.53 \mu \mathrm{g} \cdot \mathrm{mL}^{-1}\right.$ for sample $\mathrm{C}, 19.67 \mu \mathrm{g} \cdot \mathrm{mL}^{-1}$ for sample $\mathrm{H}$ and $21.03 \mu \mathrm{g} \cdot \mathrm{mL}^{-1}$ for sample $\mathrm{G}$ ).

In SRM, no growth, or no significant growth, of L. monocytogenes was observed at $3{ }^{\circ} \mathrm{C}$ and $9{ }^{\circ} \mathrm{C}$ for all tested strains (Fig. 2C). At $3{ }^{\circ} \mathrm{C}$, the populations of strains 1 and 4 decreased (1.5 log and 0.7 $\log$, respectively). No difference between the beginning and the end of incubation was observed for other strains. At $9{ }^{\circ} \mathrm{C}$, strain 1's population decreased $(0.7 \mathrm{log})$, but for other strains no difference was observed between the beginning and the end of incubation. At $15^{\circ} \mathrm{C}$, the growth of strains 3 and 5 was completely inhibited compared with the increase observed in raw milk ( $1 \log$ and $1.7 \log$, respectively). A decrease of $1.2 \mathrm{log}$ was observed for strain 4. Strains 1, 2 and 6 were able to grow; the population increases were $0.7,1.0$ and $1.3 \log$ for strains 6,1 and 2, respectively. Values given for each strain were the mean of two independent experiments. 

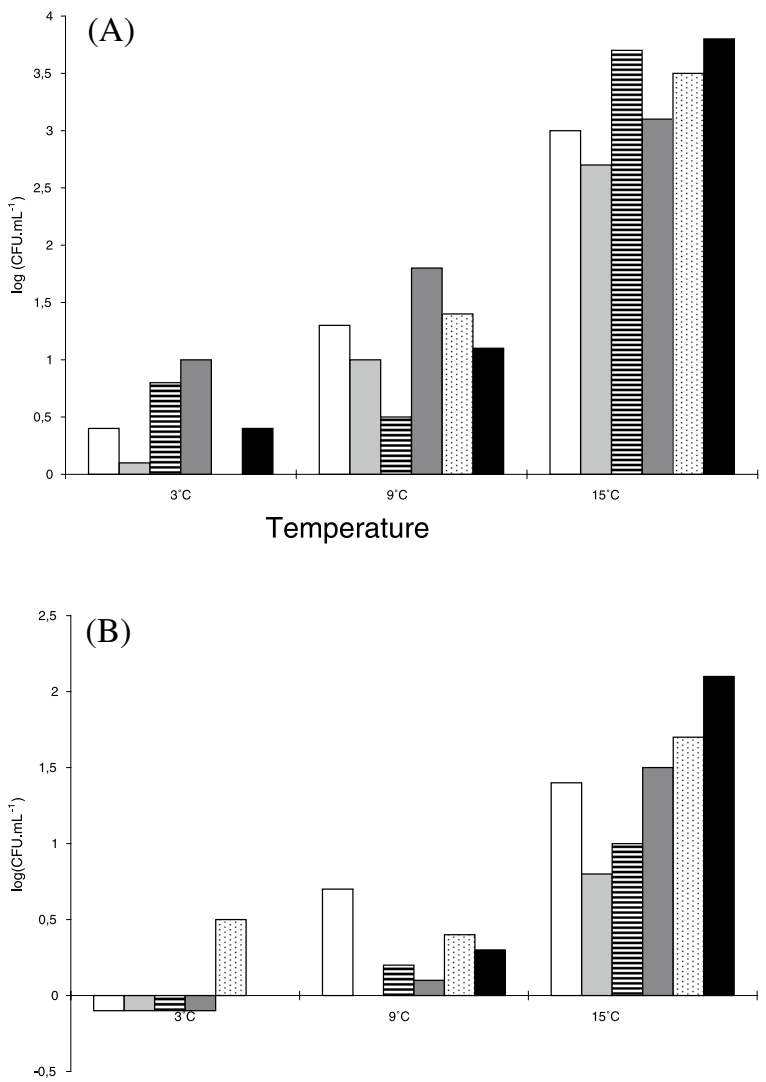

Temperature

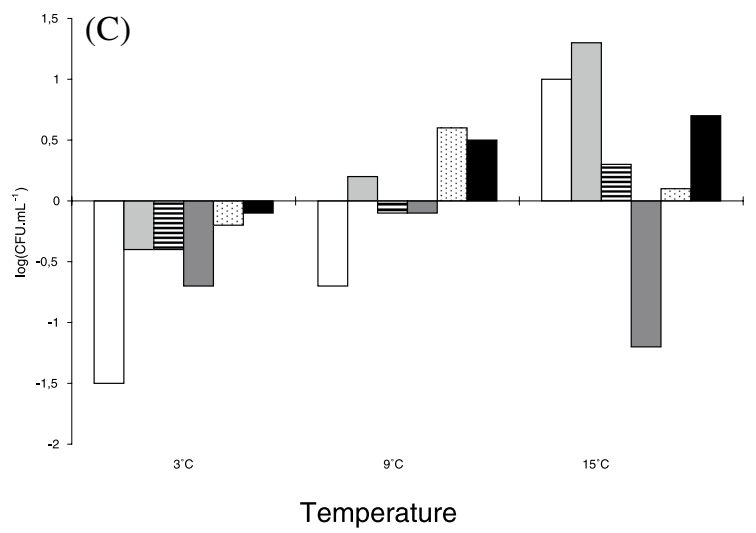

Figure 2. Difference in enumerated population of L. monocytogenes between the beginning and end of incubation (65 h) in pasteurized milk (A), in raw milk (B) and in supplemented raw milk (C). ( $\square$ :strain $1 ; \quad$ :strain 2 ; $\square$ :strain 3 ; $\square$ :strain $4 ; \square$ :strain 5 ; and $\square$ :strain 6). 


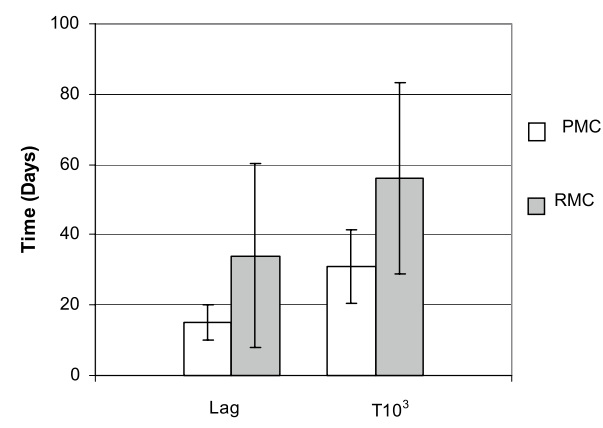

Figure 3. Average values for Lag phase and time to a $10^{3}$-fold increase in population for the six strains of L. monocytogenes in Camembert made from pasteurized (PMC) and raw milk (RMC). The bars represent the standard deviation.

\subsection{Behavior of L. monocytogenes in Camembert cheese}

Three milk samples were naturally contaminated with $L$. monocytogenes. One of them was pasteurized before making the cheese. We considered that $L$. monocytogenes enumerated in cheeses made from this pasteurized milk was the strain artificially inoculated. The two other samples were used to make cheese from raw milk. For these two samples, analysis of control cheeses of these two cheese productions showed no L. monocytogenes contamination. This result could well be due to the very low contamination level of the raw milk. We therefore considered that all the L. monocytogenes enumerated in raw cheeses from these two cheese productions were those inoculated into the raw milk; this was confirmed by the results of the PFGE profiles. For the other cheese productions, the PFGE profiles also confirmed that enumerated strains were those inoculated into the milk (results not shown).

For each experiment, the growth curve of each strain of L. monocytogenes was plotted and Lag and $\mathrm{T} 10^{3}$ were determined.

L. monocytogenes grew more slowly in RMC than in PMC. Lag and $10^{3}$ (Fig. 3) were longer in RMC than in PMC. In PMC, the average Lag was $15.1 \pm 5.0 \mathrm{~d}$, and average $\mathrm{T} 10^{3}$ was $31.1 \pm 10.5 \mathrm{~d}$. In RMC, the average Lag value was $34.1 \pm 26.0 \mathrm{~d}$ and average $\mathrm{T} 10^{3}$ was $55.9 \pm 27.2 \mathrm{~d}$. For strain 1 , $\mathrm{T} 10^{3}$ in RMC (60.9 d) was more than twice as long as in PMC (26.1 d). Growth of this strain of $L$. monocytogenes, in RMC was more than twice as slow as in PMC. For strains 3,4 and $6, \mathrm{~T}^{3} 0^{3}$ in $\mathrm{RMC}(62.5,57.5$, and $51.4 \mathrm{~d}$, respectively) was about twice as long as in PMC (34.1, 32.5 and $27.3 \mathrm{~d}$, respectively). For strains 2 and $5, \mathrm{~T}^{3} 0^{3}$ was longer in RMC (52.6 and $50.7 \mathrm{~d}$, respectively) than in PMC (35.3 and $30.4 \mathrm{~d}$, respectively). The inhibitory effect of RMC seemed to be weaker for these strains than for the others.

In RMC, both Lag and $\mathrm{T} 10^{3}$ differed widely from cheese production to cheese production (Fig. 3). Standard deviation was $26.5 \mathrm{~d}$ in RMC. The minimal and maximal values observed for Lag in RMC were 7.1 and $80 \mathrm{~d}$, respectively. The minimal and maximal values observed for $\mathrm{T}^{3} 0^{3}$ in RMC were 14.8 and $100 \mathrm{~d}$, respectively. The results obtained in PMC (Fig. 3) showed less variation than in RMC. The standard deviation observed were $5.0 \mathrm{~d}$ for Lag and $10.5 \mathrm{~d}$ for $\mathrm{T} 10^{3}$. The minimal and maximal values observed for Lag in PMC were 6.9 and $29.0 \mathrm{~d}$, respectively. The minimal and maximal values observed for $\mathrm{T}^{3} 0^{3}$ in PMC were 18.6 and $56.0 \mathrm{~d}$, respectively. These results are probably related to the microbiological and chemical components of the raw milk used in the experiment. These components may have been partly destroyed during pasteurization of the milk used to manufacture PMC.

\subsection{Effects of the variables studied on the growth of $L$. monocytogenes}

Linear correlation analysis between parameters characterizing $L$. monocytogenes growth $\left(\mathrm{Lag}\right.$ and $\left.\mathrm{T} 10^{3}\right)$ and the variables we studied (microbiological and chemical composition of raw milk) showed that Lag and $\mathrm{T} 10^{3}$ were well correlated $(0.90$, Tab. V). Lag and $\mathrm{T} 10^{3}$ were positively correlated to yeast ( 0.36 and 0.19 , respectively) and thermophilic Lactobacillus (0.48 and 0.50 , respectively). These results appear to 
Table V. Linear correlation analysis between the variables studied (microbiological and chemical composition of raw milk) and parameters characterizing growth of L. monocytogenes in raw milk cheese.

\begin{tabular}{|c|c|c|}
\hline \multirow{2}{*}{$\begin{array}{l}\text { Variable } \\
\text { (used name on correlation circle, Fig. 4) }\end{array}$} & \multicolumn{2}{|c|}{ Linear correlation coefficient with } \\
\hline & Lag a & $\mathrm{T} 10^{3} \mathrm{~b}$ \\
\hline Contaminating microflora (Conta) & 0.02 & 0.03 \\
\hline Lactococcus $(\mathrm{Lc})$ & 0.18 & 0.15 \\
\hline Streptococcus (Stept) & 0.03 & 0.17 \\
\hline Pseudomonas (Pseudo) & 0.10 & 0.24 \\
\hline Thermophilic Lactobacillus (Lbthermo) & $0.48^{c}$ & $\mathbf{0 . 5 0}{ }^{\mathrm{c}}$ \\
\hline Mesophilic Lactobacillus (Lbmeso) & -0.20 & -0.25 \\
\hline Yeast & $0.36^{c}$ & $0.19^{c}$ \\
\hline Coryneform bacteria (Coryne) & 0.17 & -0.02 \\
\hline Micrococcus (Microco) & -0.21 & -0.13 \\
\hline Lactoferrin (Lactofer) & $0.22^{c}$ & 0.17 \\
\hline M immunoglobulin (IgM) & -0.11 & 0.00 \\
\hline Lactoperoxidase (Perox) & 0.17 & $0.24^{c}$ \\
\hline Thiocyanate (Thio) & 0.07 & -0.02 \\
\hline Lag & $\mathbf{1}^{\mathrm{c}}$ & $0.90 \mathrm{c}$ \\
\hline $\mathrm{T} 10^{3}$ & $0.90^{c}$ & $1^{\mathrm{c}}$ \\
\hline
\end{tabular}

${ }^{\mathrm{a}}$ Lag phase; ${ }^{\mathrm{b}}$ time to a $10^{3}$-fold increase in population in curd; ${ }^{\mathrm{c}}$ main values of the linear correlation coefficients.

indicate an inhibitory effect of thermophilic Lactobacillus, and perhaps of yeast, on the growth of L. monocytogenes. Some chemical variables may also affect behavior of L. monocytogenes, but to a lesser extent. The correlation coefficient between lactoferrin and lactoperoxidase and the growth parameters were about 0.2 (Tab. V).

The aim of the principal components analysis was to determine the interrelations between the microbiological and chemical composition of raw milk and the growth of L. monocytogenes in cheese. In our results, three factors (or axes) explained $61.4 \%$ of the total variance (Tab. VI). Major contributors to Factor 1 (25.2\% of total variance, $\mathrm{x}$ axis in Figs. 4 and 5) were chemical variables (lactoferrin and thiocyanate). The correlation coefficients between these two variables and Factor 1 were higher than 0.8 . Factor 2 (20.1\% of total variance) was also correlated with a chemical variable: IgM. The correlation coefficient between this variable and Factor 2 (y axis in Figs. 4 and 5) was 0.75. Streptococcus was the main variable contributing to Factor 3 (16.1\% of total variance) (Tab. VI). Lag and $\mathrm{T} 10^{3}$ were not well correlated with these three factors; the correlation coefficients were between 0.30 and 0.52 (Tab. VI). From the correlation circle, it was possible to determine what variables affect the growth of L. monocytogenes. To interpret the correlation circle, one looks at the position of all variables on the diagram. Two variables close together in the diagram (for example, Lag and $\mathrm{T}^{3} 0^{3}$ ) are correlated. The correlation circle (Fig. 4) indicates that thermophilic Lactobacillus (Lbthermo) had an inhibitory effect on the growth of L. monocytogenes. The higher the thermophilic Lactobacillus concentration in the raw 
Table VI. Correlation coefficients from the Principal Components Analysis: correlation between factors and studied variables.

\begin{tabular}{|c|c|c|c|}
\hline Variable & $\begin{array}{l}\text { Factor } 1 \\
(25.2 \%)\end{array}$ & $\begin{array}{l}\text { Factor } 2 \\
(20.1 \%)\end{array}$ & $\begin{array}{l}\text { Factor } 3 \\
(16.2 \%)\end{array}$ \\
\hline Contaminating microflora & -0.61 & -0.32 & 0.06 \\
\hline Lactococcus & -0.4 & 0.60 & -0.15 \\
\hline Streptococcus & 0.14 & -0.50 & $-0.77^{\mathrm{c}}$ \\
\hline Pseudomonas & -0.03 & 0.51 & -0.52 \\
\hline Thermophilic Lactobacillus & -0.45 & 0.45 & -0.49 \\
\hline Mesophilic Lactobacillus & 0.16 & -0.47 & -0.12 \\
\hline Yeast & -0.65 & 0.26 & 0.59 \\
\hline Coryneform bacteria & -0.09 & 0.42 & 0.03 \\
\hline Micrococcus & 0.48 & -0.0 .3 & -0.64 \\
\hline Lactoferrin & $-0.87^{c}$ & -0.19 & -0.06 \\
\hline M immunoglobulin & -0.19 & $-0.75^{c}$ & -0.18 \\
\hline Lactoperoxidase & -0.66 & -0.54 & -0.38 \\
\hline Thiocyanate & $-0.81^{c}$ & -0.43 & 0.19 \\
\hline $\mathrm{Lag}^{\mathrm{a}}$ & $-0.52^{c}$ & 0.43 & -0.30 \\
\hline $\mathrm{T} 10^{3 \mathrm{~b}}$ & $-0.45^{c}$ & 0.36 & -0.47 \\
\hline
\end{tabular}

${ }^{\mathrm{a}}$ Lag phase; ${ }^{\mathrm{b}}$ time to a $10^{3}$-fold increase in population in curd; ${ }^{\mathrm{c}}$ main values of the correlation coefficients.

milk, the longer were Lag and $\mathrm{T} 10^{3}$ (hence the slower the growth). In Figure 4, the values indicated on Factors 1 and 2 (or axes $\mathrm{x}$ and y) are the coefficient correlations between the studied variables and each factor.

From the principal components analysis, we drew a diagram of the distribution of individuals on RMC (Fig. 5). An "individual" corresponds to one strain and one cheese-making date. From the distribution of individuals, clusters of individuals close together on the diagram can be shown as groups. The different cheese productions made from a given strain of L. monocytogenes are not closely located on the diagram, but strains from the same cheese-making date are very close (Fig. 5). These results indicate that the six strains of L. monocytogenes studied do not really differ in their behavior in Camembert cheese. Factors affecting the growth of L. monocytogenes seem to be linked to the cheese production (i.e. milk sample and technological parameters). In Figure 5, the values indicated on Factors 1 and 2 (or axes $\mathrm{x}$ and $\mathrm{y}$ ) are the coordinates of each point in the map designed by Factors 1 and 2 .

\section{DISCUSSION}

\subsection{Analysis of the eight milk samples used to evaluate effect of LPS in milk}

The milk samples tested throughout this study show low lactoperoxidase concentrations compared with values from the literature (30 to $70 \mu \mathrm{g} \cdot \mathrm{mL}^{-1},[1,7]$ ). Lactoperoxidase concentration is linked to lactation period [32]. Thiocyanate concentrations in the milk samples fell within the range described in the literature (between 1 and $15 \mu \mathrm{g} \cdot \mathrm{mL}^{-1}$; $[7,15])$. Thiocyanate concentration in milk 


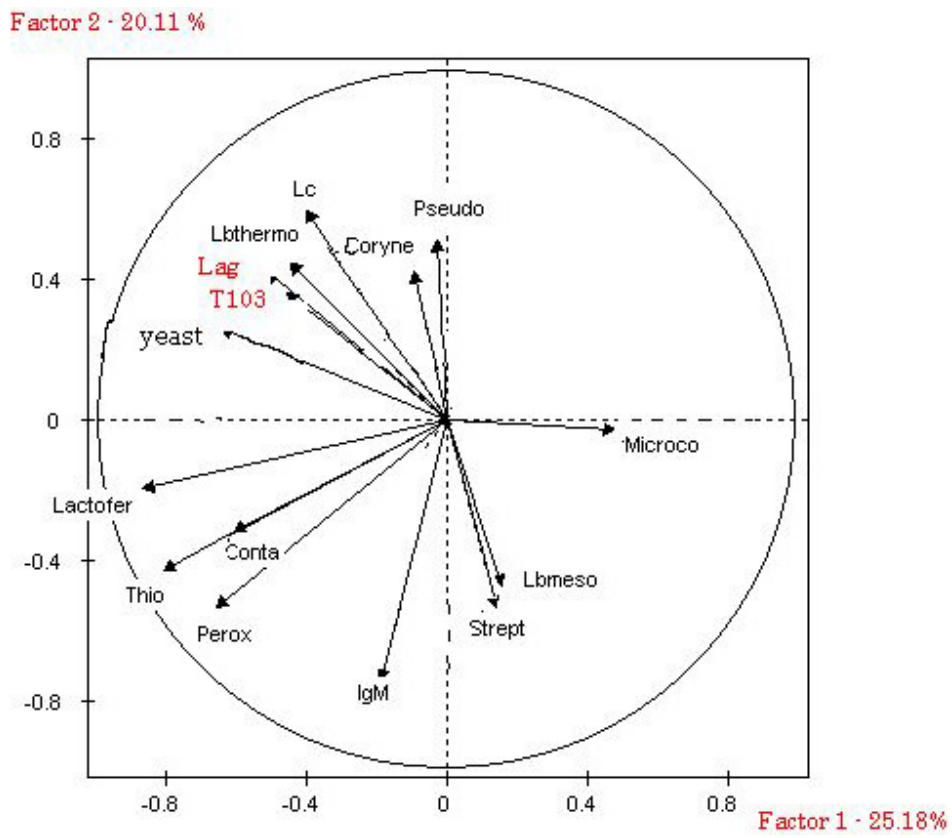

Figure 4. Correlation circle from the principal components analysis (see abbreviations Tab. V).

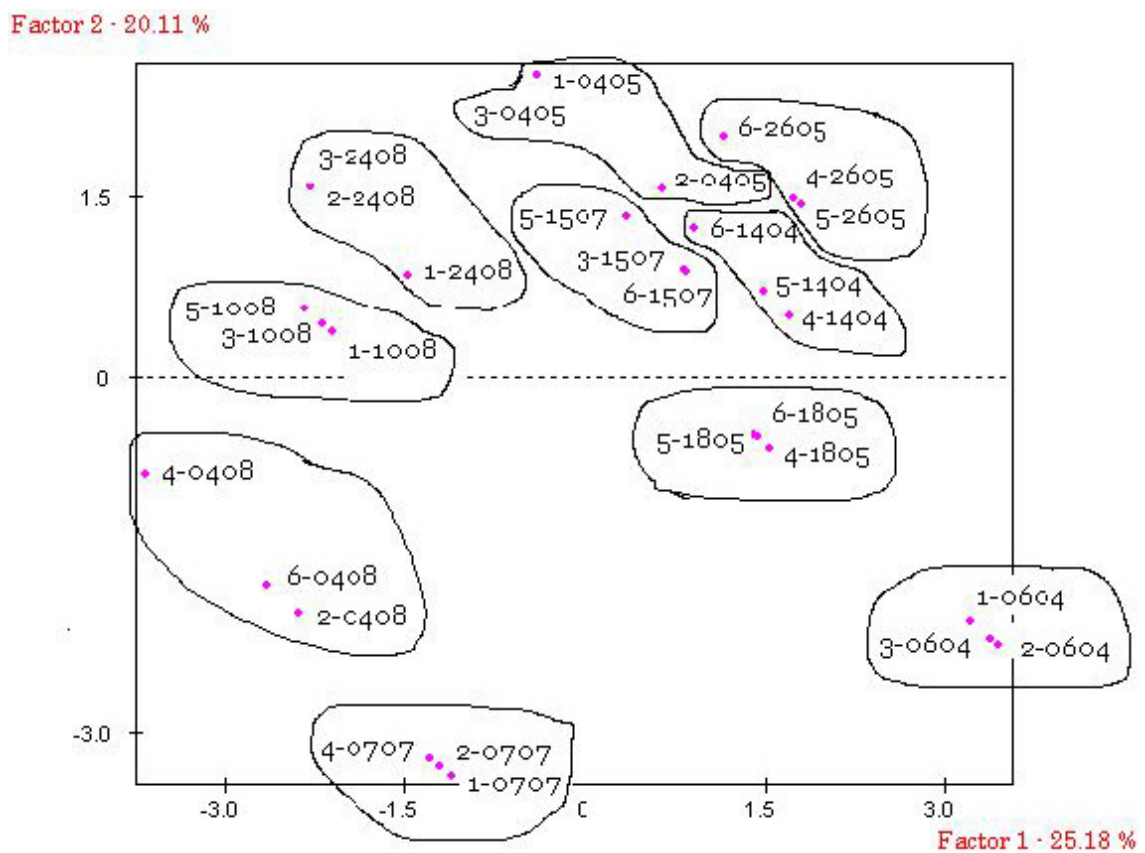

Figure 5. Individuals repartition from the principal components analysis. 
depends on the animal's diet. Cruciferae such as cabbage and cauliflower are important sources of thiocyanate in milk.

\subsection{Microbiological analysis of the eight milk samples used to evaluate effect of LPS in milk}

Raw milk samples' composition varied greatly from sample to sample. For samples $\mathrm{B}, \mathrm{C}$ and $\mathrm{H}$, the microbiological composition agrees with results described by Champagne et al. [11]: the main psychrotrophic microflora encountered in raw milk was Gramnegative bacteria rods, with Pseudomonas comprising at least $50 \%$ of the genera. Observations for samples A, D, E, F and G differ from those described in the literature. Although some Gram-positive bacteria were present in the raw milk, they were present in much smaller numbers than the Gram-negative species [11].

\subsection{Behavior of L. monocytogenes in milk}

Growth of L. monocytogenes depended not only on temperature but also on milk composition. At $3{ }^{\circ} \mathrm{C}$ for $65 \mathrm{~h}$, the L. monocytogenes population increase for strains 3 and 4 in pasteurized milk was very low (less than $1 \log$ ). No growth was observed in raw milk or SRM (Fig. 2B and 2C). At $9{ }^{\circ} \mathrm{C}$ for $65 \mathrm{~h}$, all strains except strain 3 were able to grow in pasteurized milk (Fig. 2A). In raw milk, only strain 1 was able to grow (Fig. 2B) and in SRM growth was inhibited (Fig. 2C). At $15{ }^{\circ} \mathrm{C}$ for $65 \mathrm{~h}$, population growth of L. monocytogenes strains in pasteurized milk was between $2.7 \log$ and $3.8 \log$ (Fig. 2A). In raw milk it was between $0.8 \mathrm{log}$ and $2.1 \mathrm{log}$, and in SRM the maximum increase was $1.3 \log$. L. monocytogenes grew about twice as fast in pasteurized milk as in raw milk.

Pitt et al. [33] studied the effect of raw milk on one strain of $L$. monocytogenes. The pasteurized and raw milk samples used were stored at $37^{\circ} \mathrm{C}$ for $72 \mathrm{~h}$. The initial L. monocytogenes concentration was $10^{4} \mathrm{cfu} \cdot \mathrm{mL}^{-1}$. Their results showed that L. monocytogenes was able to grow to almost $10^{7} \mathrm{cfu} \cdot \mathrm{mL}^{-1}$ in raw milk and $10^{8} \mathrm{cfu} \cdot \mathrm{mL}^{-1}$ in pasteurized milk after $16 \mathrm{~h}$ of incubation. During the remainder of the experimental period, the $L$. monocytogenes population in pasteurized milk declined to less than $10^{5} \mathrm{cfu} \cdot \mathrm{mL}^{-1}$, while in raw milk L. monocytogenes became undetectable after $56 \mathrm{~h}$ of incubation at $37^{\circ} \mathrm{C}$. The effect of raw milk on $L$. monocytogenes could result from inhibitory products produced by activation of the milk LPS. In this study [33], raw milk had a bactericidal effect on $L$. monocytogenes. Our results show only an inhibitory effect of raw milk on L. monocytogenes. This could be due to the difference in incubation temperature, as in raw milk the LPS is activated by $\mathrm{H}_{2} \mathrm{O}_{2}$ producing lactic acid bacteria $\left(\mathrm{H}_{2} \mathrm{O}_{2}-\mathrm{LAB}\right)$ that are naturally present in raw milk. Production of $\mathrm{H}_{2} \mathrm{O}_{2}$ by $\mathrm{H}_{2} \mathrm{O}_{2}$ - $\mathrm{LAB}$ may be faster at $37^{\circ} \mathrm{C}$ than at $15^{\circ} \mathrm{C}$, related to the growth of these organisms.

Our results (especially with strain 1) agree with those obtained by Gaya et al. [18]. In that study, L. monocytogenes strain Scott A was unable to grow for $3 \mathrm{~d}$ in raw milk at $4{ }^{\circ} \mathrm{C}$ and $8{ }^{\circ} \mathrm{C}$. In raw milk supplemented with thiocyanate and hydrogen peroxide, L. monocytogenes strain Scott A population decreased by $0.2 \log$ and $0.7 \log$ after $3 \mathrm{~d}$ at $4{ }^{\circ} \mathrm{C}$ and $8{ }^{\circ} \mathrm{C}$, respectively.

Some authors $[8,35,42,44]$ have studied the effect of LPS on L. monocytogenes in sterilized skim milk at $20^{\circ} \mathrm{C}$ [42], at $25^{\circ} \mathrm{C}$ [8] and at $30^{\circ} \mathrm{C}$ [44]. Their results show an inhibitory effect of the LPS on L. monocytogenes. At $20{ }^{\circ} \mathrm{C}$, without LPS, L. monocytogenes strain Scott A populations had increased by about $6.2 \mathrm{log}$ after $68 \mathrm{~h}$ [42]. In skim milk with LPS, the population increase was $2.9 \log$ after $68 \mathrm{~h}$. The difference in population increase between the control and activated skim milk was $3.3 \mathrm{log}$. Our results show a difference in population increase between pasteurized milk and SRM of $2.3 \log$ at $15^{\circ} \mathrm{C}$. At $25^{\circ} \mathrm{C}$ [8], addition of LPS inhibited the growth of L. monocytogenes strain ATCC 15313; no growth was observed for $50 \mathrm{~h}$. At $30{ }^{\circ} \mathrm{C}$, addition of lactoperoxidase inhibited the strain Scott A for $24 \mathrm{~h}$ (no growth observed). LPS also inhibited the L. monocytogenes strain Ohio at $30{ }^{\circ} \mathrm{C}$, with a difference in population increase between activated and control milk of $3 \log$ after $24 \mathrm{~h}$ [44]. 
Results obtained by Garcia-Graells et al. [16] also showed that adding LPS inhibited the growth of L. innocua in milk: no growth was observed for $24 \mathrm{~h}$ at $20^{\circ} \mathrm{C}$.

Most earlier studies have demonstrated an inhibitory effect of LPS at mild temperatures (between $20{ }^{\circ} \mathrm{C}$ and $37{ }^{\circ} \mathrm{C}$ ). Our results indicate an inhibitory effect of raw milk on L. monocytogenes at $3{ }^{\circ} \mathrm{C}, 9^{\circ} \mathrm{C}$ and $15^{\circ} \mathrm{C}$. As SRM inhibits L. monocytogenes growth more strongly than raw milk, the inhibitory effect of raw milk could be linked to the LPS.

\subsection{Behavior of L. monocytogenes in Camembert cheese}

Studies on the behavior of L. monocytogenes in soft cheeses made from pasteurized milk have been published [4, 26, 39]. Maisnier-Patin et al. [26] studied the growth of L. monocytogenes strain V7 in pasteurized milk Camembert. The concentrations of L. monocytogenes in milk were $10^{5}$ and $10^{1} \mathrm{cfu} \cdot \mathrm{mL}^{-1}$. The observed lag phases were 7 and $14 \mathrm{~d}$, respectively. In the present study, (with an initial L. monocytogenes concentration of $5 \times 10^{-1} \mathrm{cfu} \cdot \mathrm{mL}^{-1}$ ), average lag values varied from 11 to $19.2 \mathrm{~d}$ depending on the strain. The Lag phase observed with a high initial concentration of $L$. monocytogenes $\left(10^{5} \mathrm{cfu} \cdot \mathrm{mL}^{-1}\right)$ was shorter than those observed with low initial concentrations [26]. Some studies report the effect of inoculum concentration on the growth of L. monocytogenes $[3,12,17]$. Our results differed from one other study [4], where the initial concentration was $3 \times 10^{2} \mathrm{cfu} \cdot \mathrm{mL}^{-1}$, lag phase was between 10 and $15 \mathrm{~d}$ and population increased $10^{3}$-fold over $40 \mathrm{~d}$. The difference between these and our results may be related to the strains studied, all isolated from raw milk.

Other studies have investigated the behavior of L. monocytogenes in cheese made from raw cow's milk [34, 37] and from raw goat's milk [29]. L. monocytogenes did not grow in semi-hard raw cheese at $12{ }^{\circ} \mathrm{C}$ for $60 \mathrm{~d}$ [37]. One study [34] deals with the behavior of $L$. monocytogenes in pasteurized and raw Camembert. Ripening was at $12{ }^{\circ} \mathrm{C}$ for $10 \mathrm{~d}$, and the cheeses were then stored at $2{ }^{\circ} \mathrm{C}$ for $50 \mathrm{~d}$. The initial con- centration of L. monocytogenes in the milk was $10^{4} \mathrm{cfu} \cdot \mathrm{mL}^{-1}$. The lag phase was between 10 and $30 \mathrm{~d}$ in both raw and pasteurized cheese. The population increase at the end of the storage period was 1.84 and $2.08 \log \left(\mathrm{cfu} \cdot \mathrm{g}^{-1}\right)$ in raw and pasteurized cheese, respectively. In this study, the inhibitory effect of raw milk was less significant than our results show. This may be linked to the initial concentration of $L$. monocytogenes used and the microbiological and chemical composition of the raw milk. Morgan et al. [29] studied the behavior of L. monocytogenes in soft cheese made from raw goat's milk. Initial concentrations of L. monocytogenes in the milk were $10^{1}$ and $10^{2} \mathrm{cfu} \cdot \mathrm{mL}^{-1}$. The authors observed that when the initial concentration was $10^{2} \mathrm{cfu} \cdot \mathrm{mL}^{-1}$, L. monocytogenes did not grow, but survived throughout the 42-day experiment. When the initial concentration was $10^{1} \mathrm{cfu} \cdot \mathrm{mL}^{-1}$, L. monocytogenes survived for $7 \mathrm{~d}$ on the surface and for $42 \mathrm{~d}$ inside the cheese. This study showed that the initial concentration of $L$. monocytogenes in milk affects the behavior of the pathogen in cheese. The inhibition of L. monocytogenes in raw goat's soft cheese is probably related to $\mathrm{pH}$. In the curd, $\mathrm{pH}$ was 4.25; after $21 \mathrm{~d}$ it increased to 6 on the cheese's surface. Inside the cheese the $\mathrm{pH}$ was less than 5.5 after $42 \mathrm{~d}$. In Camembert cheese made from cow's milk, the curd $\mathrm{pH}$ was 4.5 , increasing to 6 after $3 \mathrm{~d}$ on the surface and $28 \mathrm{~d}$ inside the cheese [26]. The behavior of L. monocytogenes in determined conditions was not only related to initial bacterial concentration but also to the physiological conditions of the cells [21].

To evaluate the behavior of L. monocytogenes in food, the initial concentration used should be as close as possible to concentrations found in naturally contaminated food. This is the case in our study (initial concentration of $0.5 \mathrm{cfu} \cdot \mathrm{mL}^{-1}$; the most probable concentration in collected raw milk is $\left.0.1 \mathrm{cfu} \cdot \mathrm{mL}^{-1},[28]\right)$.

\subsection{Effects of the variables studied on the growth of $L$. monocytogenes}

The inhibitory effect of lactic acid bacteria $(\mathrm{LAB})$ is well documented $[11,27$, 
37]. These studies refer to mesophilic and thermophilic LAB. Our results agreed with these studies, as thermophilic Lactobacillus inhibited the growth of L. monocytogenes.

Inhibition of L. monocytogenes growth by LPS (lactoperoxidase and thiocyanate) and lactoferrin is extensively described in the literature $[5,8,9,11,30,32,44]$. Bellamy et al. [5] showed that the growth of L. monocytogenes was affected by lactoferrin (concentrations between 0.3 and $150 \mu \mathrm{g} \cdot \mathrm{mL}^{-1}$ ). Our results did not clearly demonstrate an inhibitory effect of the chemical composition of raw milk on subsequent growth of L. monocytogenes in cheese.

\section{CONCLUSION}

Our results demonstrate that $L$. monocytogenes grows more slowly in raw and in supplemented raw milk than in pasteurized milk. The inhibitory effect of raw milk is partly due to the LPS. Moreover, an inhibitory effect of RMC compared with PMC was observed. Growth of L. monocytogenes in RMC was about twice as long as in PMC. This inhibitory effect was mainly observed in the lag phase (Lag in RMC was 2.3 times as long as in PMC and $\mathrm{T} 10^{3}$ in RMC was 1.9 times as long as in PMC). The inhibitory effect of RMC on the growth of L. monocytogenes was mainly related to the microbiological composition of the raw milk, in terms of thermophilic Lactobacillus and yeast. High yeast concentrations in the raw milk mainly induced an increase in the lag phase. The inhibitory effect of thermophilic Lactobacillus was observed on both Lag and $\mathrm{T} 10^{3}$. The results obtained suggest that yeast has an inhibitory effect on L. monocytogenes. To our knowledge, inhibition of $L$. monocytogenes by yeast has not been previously described. There is a need to investigate the interrelationship between yeast and L. monocytogenes. To acquire a more thorough knowledge of the effects of chemical and microbiological factors on the behavior of L. monocytogenes, it would be useful to quantify these factors in cheese. Our results did not clearly demonstrate an inhibitory effect of the chemical composi- tion of raw milk on the subsequent growth of $L$. monocytogenes in cheese.

The results of this study clearly demonstrate (i) the inhibitory effect of raw milk on the growth of L. monocytogenes and (ii) the inhibitory effect of raw milk cheese on the growth of L. monocytogenes compared with pasteurized milk cheese. The inhibitory effect of RMC was mainly related to the microbiological composition of the raw milk.

The inhibition of L. monocytogenes in Camembert-type surface-ripened cheese made from raw milk, as shown in the present paper, is probably a contributing factor to the food safety of this cheese [41].

Acknowledgments: We thank Dr. Salmon (Institut National de la Recherche Agronomique, Poligny, France) for chemical analysis of the milk and G. Garric (CETAA La Lande du Breil, Rennes, France) for enabling us to make the experimental cheeses. The research was partially funded by the Office National Interprofessionnel du Lait et des Produits Laitiers (ONILAIT, Paris, France). The authors thank J.B. Miollière, A.-M. Revol (ENSAIA-INPL, École Nationale Supérieure d'Agronomie et d'Industries Alimentaires - Institut National Polytechnique de Lorraine, Vandœuvre-les-Nancy, France), J. Rocourt (WHO, Geneva, Switzerland) and O. Cerf (École Nationale Vétérinaire d'Alfort, Maisons-Alfort, France) for reviewing this paper.

\section{REFERENCES}

[1] Alais C., Science du lait : principes des techniques laitières, Sepiac, Paris, France, 1984.

[2] Anonymous, Méthode horizontale pour la recherche et le dénombrement de Listeria monocytogenes - Partie 1: Méthode de recherche - Standard NF EN ISO 11290-1 (1997).

[3] Augustin J.-C., Brouillaud-Delattre A., Rosso L., Carlier V., Significance of inoculum size in the lag time of Listeria monocytogenes, Appl. Env. Microbiol. 66 (2000) 1706-1710.

[4] Back J.P., Langford S.A., Kroll R.G., Growth of Listeria monocytogenes in Camembert and other soft cheeses at refrigeration temperatures, J. Dairy Res. 60 (1993) 421-429.

[5] Bellamy W., Takase M., Wakabayashi H., Kawase K., Tomika M., Antibacterial spectrum of lactoferrin $\mathrm{B}$, a potent bactericidal 
peptide derived from the $\mathrm{N}$-terminal region of bovine lactoferrin, J. Appl. Bacteriol. 73 (1992) 472-479.

[6] Bemrah W., Sanna M., Cassin M.H., Griffiths M.W., Cerf O., Quantitative risk assessment of L. monocytogenes in soft cheeses made from raw milk, Prev. Vet. Med. 37 (1998) 129-145.

[7] Boudier F.K., Biocatalyseurs : les enzymes, in: Luquet F.M. (Ed.), Lait et Produits Laitiers ; vache - brebis - chèvre, Vol. 1 : les laits de la mamelle à la laiterie, Lavoisier Tec et Doc - Apria , Paris, 1985, pp. 62-74.

[8] Boussouel N., Mathieu F., Revol-Junelles A.-M., Millière J.B., Effects of combinations of lactoperoxidase system and nisin on the behavior of Listeria monocytogenes ATCC 15313 in skim milk, Int. J. Food Microbiol. 61 (2000) 169-175.

[9] Branen J., Davidson P.M., Activity of hydrolysed lactoferrin against foodborne pathogenic bacteria in growth media: the effect of EDTA, Lett. Appl. Microbiol. 30 (2000) 233-237.

[10] Brosch R., Buchrieser C., Rocourt J., Subtyping of Listeria monocytogenes serovar-4b by use of low-frequency-cleavage restriction endonuclease and pulsed-field electrophoresis, Res. Microbiol. 142 (1991) 667-675.

[11] Champagne C.P., Laing R.R., Roy D., Mafu A.A., Griffiths M.W., Psychrotrophs in dairy products: their effects and their control, Crit. Rev. Food Sci. Nutr. 34 (1994) 1-30.

[12] Chen Y., Ross W.H., Scott V.N., Gombas D.E., Listeria monocytogenes: low levels equal low risk, J. Food Prot. 66 (2003) 570-577.

[13] Comi G., Frigerio R., Cantoni C., Listeria monocytogenes serotypes in Italian meat products, Lett. Appl. Microbiol. 15 (1992) 168171.

[14] Farber J.M., Peterkin P.I., Listeria monocytogenes, a foodborne pathogen, Microbiol. Rev. 55 (1991) 476-511.

[15] Fonteh F.A., Grandison A.S., Lewis M.J., Variations of lactoperoxidase activity and thiocyanate content in cows' and goats' milk throughout lactation, J. Dairy Res. 69 (2002) 401-409.

[16] Garcia-Graells C., Valckx C., Michiels C.W., Inactivation of Escherichia coli and Listeria monocytogenes in milk by combined treatment with high hydrostatic pressure and the lactoperoxidase system, Appl. Environ. Microbiol. 60 (2000) 4173-4179.

[17] Gay M., Cerf O., Davey K.R., Significance of pre-incubation temperature and inoculum concentration on subsequent growth of Listeria monocytogenes at $14{ }^{\circ} \mathrm{C}$, J. Appl. Bacteriol. 81 (1996) 433-438.
[18] Gaya P., Medina M., Nunez M., Effect of lactoperoxidase system on Listeria monocytogenes behavior in raw milk at refrigeration temperatures, Appl. Environ. Microbiol. 57 (1991) 3355-3360.

[19] George S.M., Lund B.M., Brocklehurst T.K. The effect of $\mathrm{pH}$ and temperature on initiation of growth of Listeria monocytogenes, Lett. Appl. Microbiol. 6 (1988) 153-156.

[20] Harvey J., Gilmour A., Occurrence of Listeria species in raw milk and dairy products produced in Northern Ireland, J. Appl. Bacteriol. 72 (1992) 119-125.

[21] Helloin E., Bouttefroy A., Gay M., Phan Thanh L., Impact of preheating on the behavior of Listeria monocytogenes in a broth that mimics Camembert cheese composition, J. Food Prot. 66 (2003) 265-271.

[22] Hoogendoorn H., Piessens J.P., Scholtes W., Stoddard L.A., Hypothiocyanite ion; the inhibitor formed by the system lactoperoxidase-thiocyanate-hydrogen peroxide, Caries Res. 11 (1977) 77-84.

[23] Hudson W.R., Mead G.C., Listeria contamination at a poultry processing plant, Lett. Appl. Microbiol. 9 (1989) 211-214.

[24] Kumar R., Bhatia K.L., Standardization of method for lactoperoxidase assay in milk, Lait 79 (1999) 269-274.

[25] Lund A.M., Zottola E.A., Pusch D.J., Comparison of methods for isolation of Listeria from raw milk, J. Food Prot. 54 (1991) 602605.

[26] Maisnier-Patin S., Deschamps N., Tatini S.R., Richard J., Inhibition of Listeria monocytogenes in Camembert cheese made with a nisin-producing starter, Lait 72 (1992) 249263.

[27] Mathew F.P., Ryser E.T., Competition of thermally injured Listeria monocytogenes with a mesophilic lactic acid starter culture in milk for various heat treatments, J. Food Prot. 65 (2002) 643-650.

[28] Meyer-Broseta S., Diot A., Bastian S., Rivière J., Cerf O., Estimation of low bacteria concentration: Listeria monocytogenes in raw milk, Int. J. Food Microbiol. 80 (2002) $1-15$.

[29] Morgan F., Bonnin V., Mallereau M.P., Perrin G., Survival of Listeria monocytogenes during manufacturing, ripening and storage of soft lactic cheese made from raw goat milk, Int. J. Food Microbiol. 64 (2001) 212-221.

[30] Murdock C.A., Matthews K.R., Antibacterial activity of pepsin-digested lactoferrin on foodborne pathogens in buffered broth systems and ultra-high temperature milk with EDTA, J. Appl. Microbiol. 93 (2002) 850-856. 
[31] Papageorgiou D.K., Marth E.H., Fate of Listeria monocytogenes during the manufacture, ripening and storage of Feta cheese, J. Food Prot. 52 (1989) 82-87.

[32] Perraudin J.P., Lactoperoxidase: a natural preservative, Dairy Ind. Int. 56 (1991) 22-24.

[33] Pitt W.M., Harden T.J., Hull R.R., Investigation of the antimicrobial activity of raw milk against several foodborne pathogens, Milchwissenschaft 55 (2000) 249-252.

[34] Ramsaran H., Chen J., Brunke B., Hill A., Griffiths M.W., Survival of bioluminescent Listeria monocytogenes and Escherichia coli O157:H7 in soft cheeses, J. Dairy Sci. 81 (1998) 1810-1817.

[35] Ravishankar S., Harrison M.A., Acid adaptation of Listeria monocytogenes strains does not offer cross-protection against an activated lactoperoxidase system, J. Food Prot. 62 (1999) 670-673.

[36] Rocourt J., Listeria monocytogenes: the state of the science, Dairy Food Environ. San. 14 (1994) 70-82.

[37] Rodriguez E., Arques J.L., Gaya P., Nunez M., Medina M., Control of Listeria monocytogenes by bacteriocin-producing lactic acid bacteria by colony hybridization in semihard raw milk cheese, J. Dairy Res. 68 (2001) 131-137.

[38] Ryser E.T., Incidence and behavior of Listeria monocytogenes in unfermented dairy products, in: Ryser E.T., Marth E.H. (Eds.), Lis- teria, Listeriosis and Food Safety, 2nd edn., Marcel Dekker Inc., New-York - Basel, 1999, pp. 359-409.

[39] Ryser E.T., Marth E.H., Fate of Listeria monocytogenes during the manufacture and ripening of camembert cheese, J. Food Prot. 50 (1987) 372-378.

[40] Sanaa M., Poutrel B., Menard J.L., Serieys F., Risk factors associated with contamination of raw milk by L. monocytogenes in dairy farms, J. Dairy Sci. 76 (1993) 2891-2898.

[41] Sanaa M., Coroller L., Cerf O., Risk assessment of listeriosis linked to the consumption of two soft cheeses made from raw milk: Camembert of Normandy and Brie de Meaux, Risk Anal. 24 (2004) 389-399.

[42] Siragusa G.R., Johnson M.G., Inhibition of Listeria monocytogenes growth by the lactoperoxidase-thiocyanate- $\mathrm{H}_{2} \mathrm{O}_{2}$ antimicrobial system, Appl. Environ. Microbiol. 55 (1989) 2802-2805.

[43] Slutsker L., Schuchat A., Listeriosis in Humans, in: Ryser E.T., Marth E.H. (Eds.), Listeria, Listeriosis and Food Safety, 2nd edn., Marcel Dekker Inc., New-York-Basel, 1999, pp. 75-95.

[44] Zapico P., Medina M., Gaya P., Numez M., Synergic effect of nisin and the lactoperoxidase system on Listeria monocytogenes in skim milk, Int. J. Food Microbiol. 40 (1998) 35-42. 